\title{
Effects of Extraction Methods and Conditions on Bioactive Compounds Extracted from Phaeodactylum tricornutum
}

\author{
Saniye Akyıl, ${ }^{1}$ Işıl İlter, ${ }^{1}$ Mehmet Koç,,${ }^{2}{ }^{\star}$ Zeliha Demirel, ${ }^{3}$ Ayşegül Erdoğan, \\ Meltem Conk Dalay ${ }^{3}$ and Figen Kaymak Ertekin ${ }^{1}$ \\ ${ }^{1}$ Faculty of Engineering, Food Engineering Department, Ege University, Bornova, 35100, İzmir, Turkey, \\ ${ }^{2}$ Faculty of Engineering, Food Engineering Department, Aydin Adnan Menderes University, 09010, Aydin, Turkey, \\ ${ }^{3}$ Faculty of Engineering, Bio Engineering Department, Ege University, Bornova, 35100, İzmir, Turkey, \\ ${ }^{4}$ Ege University Application and Research Center for Testing and Analysis (EGE MATAL), Bornova, 35100, İzmir, Turkey, \\ *Corresponding author: E-mail: mehmetkoc@adu.edu.tr \\ Tel.: 902562137503
}

Received: 05-30-2020

\begin{abstract}
The effect of homogenization, ultrasound and microwave extraction methods and conditions on fucoxanthin content, total phenolic content and antioxidant activity of extracts obtained from Phaeodactylum tricornutum were investigated in this study. The solvent/biomass ratio was the most effective parameter on fucoxanthin content, total phenolic content and antioxidant activity. The maximum fucoxanthin content $(5.60 \pm 0.06 \mathrm{mg} / \mathrm{g})$ and antioxidant activity $(763.00 \pm 15.88$ $\mathrm{EC}_{50} \mu \mathrm{g} / \mathrm{mL}$ extract) were obtained with the homogenization extraction method whose optimum conditions were $1.93 \%$ biomass/solvent ratio, $\sim 5200 \mathrm{rpm}$ homogenization rate and $14.2 \mathrm{~min}$ extraction time. Although the ultrasonic extraction method has reached the approximately same level of fucoxanthin content $(5.24 \pm 0.07 \mathrm{mg} / \mathrm{g})$ ), TPC $(67.68 \pm 1.58 \mathrm{mg}$ gallic acid/L) and antioxidant activity $\left(619.90 \pm 17.16 \mathrm{EC}_{50} \mu \mathrm{g} / \mathrm{mL}\right.$ extract $)$ at an amplitude of $55.72 \%$, a higher biomass/ solvent ratio $(2.72 \%)$ and a longer extraction time $(17.37 \mathrm{~min})$ have been required. The lowest fucoxanthin content, total phenolic content and antioxidant activity were determined for the microwave extraction method.
\end{abstract}

Keywords: Fucoxanthin; microwave extraction; optimization; Phaeodactylum tricornutum; total phenolic compounds; ultrasonic extraction

\section{Introduction}

Fucoxanthin (orange-yellow pigment), a major marine xanthophyll present in the chloroplasts of micro and macroalgae, contains more than $10 \%$ of approximate sum of carotenoid production in fresh and marine water. ${ }^{1,2} \mathrm{Fu}-$ coxanthin has uncommonly structure with an allenic bond, epoxy, hydroxyl, carbonyl and carboxyl parts and is metabolized into fucoxanthinol, amarouciaxanthin $\mathrm{A}$, and halocynthiaxanthin after absorption detected in rats and mice plasma and the liver. ${ }^{3,4}$ Recently, several studies were indicated that fucoxanthin and its bioactive compounds have useful pharmaceutical properties including anticancer, antihypertensive, anti-inflammatory, antidiabetic and anti-obesity activities. ${ }^{5-7}$ Additively, it has indicated that the protective properties on liver, blood vessels of the brain, bones, skin, and eyes. ${ }^{8}$

Extraction of fucoxanthin is mostly obtained from the waste of brown seaweeds, abundantly harvested in Asia. ${ }^{9}, 10$ However, microalgae are also considered as potential source of fucoxanthin for industrial production. The concentration of fucoxanthin in diatom contains of $2.24-18.23 \mathrm{mg} / \mathrm{g}$ dry weight while in macroalgae includes about $0.1-1 \mathrm{mg} / \mathrm{g}$ amount of dry cell weight. ${ }^{11-13}$ For this reason, large scale production from a diatom that produces fucoxanthin in high amounts has attracted more attention nowadays.

Phaeodactylum tricornutum, a single-cell microalgae belonging to the Bacillariophyta, is a diatom species living 
in the marine environment. ${ }^{14}$ It biosynthesizes proteins, fats, carbohydrates, minerals, pigments, hydrocarbons, polysaccharides, phenolic compounds, antibiotics and many other metabolites that is commonly utilized in feed source in aquaculture. It can be used as a source of. P. tricornutum is typically rich in eicosapentaenoic acid (EPA), long chain unsaturated fatty acids (PUFAs) and has a high content of the carotenoid fucoxanthin. ${ }^{15,16}$ Fucoxanthin, antioxidant compounds, which is part of the photosynthetic apparatus of microalgae for participates in photo protection from excess light. ${ }^{17}$ Moreover, McClure et al. ${ }^{18}$ explained that the productivity of fucoxanthin from $P$. tricornutum determines enhancing using various culture conditions such as the light intensity, medium composition and $\mathrm{CO}_{2}$ addition on production. The difficulty and low efficiency in chemical synthesis limits the industrial production of fucoxanthin. The diatoms have not only xanthophyll but also phenolic compounds and both of them are emphasized strongly possessing antioxidant activity. ${ }^{19}$

In general, various extraction methods of bioactive compounds has its own advantages and disadvantages therefore it is necessary to determine the most appropriate extraction method of the biomass being studied by considering factors such as the extraction time, cost, yield and purity. Many of the studies focused on extraction of fucoxanthin from $P$. tricornutum, little attention has been paid for its efficient extraction by altering some variables systematically using response surface methodology.

In this study, it was used to optimize following Central Composite Rotatable Design (CCRD) the extraction conditions of fucoxanthin and phenolic compounds from P. tricornutum. The aim of this study was to compare different extraction methods (homogenization solvent, ultrasound and microwave assisted extraction methods) for the recovery of fucoxanthin from frozen biomass of $P$. tricornutum and their conditions targeting maximum fucoxanthin content, acceptable amount of total phenolic compounds with antioxidant activity using response surface methodology.

\section{Experimental}

\section{1. Microorganism}

Phaeodactylum tricornutum Bohlin EGEMACC 71 was supplied from the Ege University Microalgae Culture Collection (http://www.egemacc.com/) in Izmir, Turkey. In the microalgal biotechnology laboratory of Ege University, $P$. tricornutum was cultured using $\mathrm{F} / 2$ medium, ${ }^{20}$ in laboratory photobioreactors at $55 \mu \mathrm{mol}$ photons $/ \mathrm{m}^{2} \mathrm{~s}$ light intensity, aerated with air bubbles at $2 \mathrm{~L} / \mathrm{min}$ and incubated at $20 \pm 2{ }^{\circ} \mathrm{C}$. After exponential phase, $P$. tricornutum cells were harvested by centrifuge (PrO-Research, Centrium Scientific Limited, UK) on the fourteenth day and the biomass stored at $-20^{\circ} \mathrm{C}$ under dark conditions for using. ${ }^{21}$

\section{2. Chemicals}

Folin-Ciocalteu reagent (Merck, Darmstadt, Germany), sodium carbonate (Fisher Science, UK) and gallic acid (Merck, Darmstadt, Germany) were measured by total phenolic content. Trolox (Hoffman-La Roche) (6-hydroxy-2,5,7,8-tetramethychroman-2-carboxylic acid; Aldrich Chemical Co., Gillingham, Dorset, UK) was as applied as a standard antioxidant. Ethanol (Merck, Darmstadt, Germany), Ethanol (32205-2.5 L) was supplied from Sigma-Aldrich Chemical Co. (Steinheim, Germany) and used in the extraction protocol. HPLC-DAD standards, alltrans fucoxanthin (16337-1 mg) and all-trans-neoxanthin (54764-1 mg) were purchased from also Sigma-Aldrich Chemical Co. (Steinheim, Germany). Methanol and acetonitrile (LC-grade) were purchased from Merck (Darmstadt, Germany) for the HPLC-DAD analysis of extracts.

\section{3. Extraction Methods of $P$. tricornutum}

Fucoxanthin and total phenolics were extracted from P. tricornutum frozen biomass in $80 \%$ ethanol/water $(\mathrm{v} / \mathrm{v})$. The freezing of biomass was collected in a freezer (Arçelik, Model 5223, Turkey) at $-20 \pm 2{ }^{\circ} \mathrm{C}$ for using when the drying process was performed in a drying oven (Vacucell 22, USA) at $50 \pm 2{ }^{\circ} \mathrm{C}$ until it reached to approximately $6 \%$ moisture content. To detect the effect of freezing biomass form on fucoxanthin concentration the amount of dry matter content of the biomass in the extraction medium was kept constant.

Homogenization extraction (CE), Microwave extraction (ME) and Ultrasound extraction (UE) techniques were applied to use a mechanical homogenizer, a microwave extraction device (Milestone, Start E, Italy), and an ultrasound bath (Daihan Wisd WUC-D06H, Korea) respectively. ${ }^{22}$ In CE and UE process, the temperature of the extraction medium was kept constant at $25 \pm 2{ }^{\circ} \mathrm{C}$ with the circulator water bath whereas in the ME process, the temperature in the extraction chamber didn't exceed $40 \pm 2{ }^{\circ} \mathrm{C}$.

\section{4. Optimization of the Extraction Protocol}

The effect of extraction process variables (time, biomass/solvent ratio, homogenization rate, amplitude, microwave power) on fucoxanthin content, total phenolic content and DPPH antioxidant activity of extracts was investigated following Central Composite Rotatable Design (CCRD) as given in Table 1

The optimum homogenization rate $(\mathrm{rpm})$ for $\mathrm{CE}$, amplitude for UE, microwave power for ME, time (min) and biomass/solvent ratio (\%) was determined targeting the maximum concentration of fucoxanthin and acceptable amount of total phenolic content (TPC) and DPPH antioxidant activity considering desirability function approach. $80 \%$ ethanol ( $\mathrm{v} / \mathrm{v})$ was used as an extraction medium for all the extraction methods. 
Table 1. Extraction process variables and levels for the specific CCRD experimental design

\begin{tabular}{|c|c|c|c|c|c|c|c|}
\hline \multirow[t]{2}{*}{ Extraction Method } & \multirow[t]{2}{*}{ Independent Variables } & & \multicolumn{5}{|c|}{ Coded Values } \\
\hline & & & -1.682 & -1 & $\mathbf{0}$ & 1 & 1.682 \\
\hline \multicolumn{8}{|l|}{ Homogenization } \\
\hline \multirow[t]{3}{*}{ Extraction (CE) } & Biomass/Solvent Ratio (\%) & $(\mathrm{A})$ & 0.32 & 1 & 2 & 3 & 3.68 \\
\hline & Hom. Rate (rpm) & (B) & 3636 & 5000 & 7000 & 9000 & 10363 \\
\hline & Time (min) & (C) & 1.59 & 5 & 10 & 15 & 18.41 \\
\hline \multicolumn{8}{|l|}{ Ultrasonic } \\
\hline \multirow[t]{3}{*}{ Extraction (UE) } & Biomass/Solvent Ratio (\%) & (A) & 0.32 & 1 & 2 & 3 & 3.68 \\
\hline & Amplitude (\%) & (D) & 19.77 & 30 & 45 & 60 & 70.23 \\
\hline & Time (min) & (C) & 4.89 & 10 & 17.5 & 25 & 30.11 \\
\hline \multicolumn{8}{|l|}{ Microwave } \\
\hline \multirow[t]{3}{*}{ Extraction (ME) } & Biomass/Solvent Ratio (\%) & (A) & 0.32 & 1 & 2 & 3 & 3.68 \\
\hline & Power (W) & $(\mathrm{E})$ & 65.91 & 100 & 150 & 200 & 234.09 \\
\hline & Time (s) & (C) & 19.09 & 60 & 120 & 180 & 220.91 \\
\hline
\end{tabular}

The process parameters specific to each extraction method, biomass/solvent ratio (\%) and extraction time were optimized to provide Multiple regression analysis was carried out for fitting the Eq. $(1,2$, and 3$)$ to the experimental data and significant terms of the model were measured by ANOVA. The CCRD and the corresponding data analysis were implemented by using the Design-Expert 7.0.0 (Stat-Ease Inc., MN, USA). anthin $(0.5-5 \mathrm{mg} / \mathrm{L})$ using internal standard as neoxanthin according to the procedure applied in previous studies. ${ }^{23}$

\section{5. 2. DPPH Antioxidant Activity}

The antioxidant activity of the extracted samples was investigated by the DPPH (2,2-diphenyl-1-picrylhydrazyl radical scavenging capacity) method. The DPPH solution

$$
\begin{aligned}
& F X=\beta_{0}+\sum_{i=1}^{k} \beta_{i} x_{i}+\sum_{i=1}^{k} \beta_{i i} x_{i}^{2}+\sum_{i=1}^{k-1} \sum_{j=i+1}^{k} \beta_{i j} x_{j i}(k=1,2,3) \\
& T P C=\beta_{0}+\sum_{i=1}^{k} \beta_{i} x_{i}+\sum_{i=1}^{k} \beta_{i i} x_{i}^{2}+\sum_{i=1}^{k-1} \sum_{j=i+1}^{k} \beta_{i j} x_{j i}(k=1,2,3) \\
& D P P H=\beta_{0}+\sum_{i=1}^{k} \beta_{i} x_{i}+\sum_{i=1}^{k} \beta_{i i} x_{i}^{2}+\sum_{i=1}^{k-1} \sum_{j=i+1}^{k} \beta_{i j} x_{j i}(k=1,2,3)
\end{aligned}
$$

\section{5. Analysis}

\subsection{Fucoxanthin Analysis}

The extracts were centrifuged using a refrigerated centrifuge (Nuve NF400, Turkey) at $4000 \mathrm{rpm}, 10$ minutes at $20{ }^{\circ} \mathrm{C}$ and supernatant was passed through a filtration apparatus (PTFE filter with a diameter of $0.20 \mu \mathrm{m}$ ) to remove the cell residue. The amount of fucoxanthin in the extracts was determined by HPLC-DAD (Agilent 1260, USA) using YMC carotenoid $\mathrm{C}_{30}$ column $(25 \mathrm{~cm}, 4.6 \mathrm{ID}, 5$ $\mu \mathrm{m})$. For the separation of fucoxanthin, 70:30 methanol: acetonitrile $(\mathrm{v} / \mathrm{v})$ was used as the mobile phase at a flow rate of $1 \mathrm{~mL} / \mathrm{min}$. Under these conditions, standards fucoxanthin and neoxanthin gave an absorbance at $450 \mathrm{~nm}$ and 442 $\mathrm{nm}$, respectively. Therefore, peak areas are considered at these wavelengths.

Retention times for fucoxanthin (FX) and neoxanthin (NX) were 7 and 9 minutes, respectively, as determined by HPLC-DAD. Calibration curve was constructed for fucox- of measuring the ability to inhibit free radicals was used and the reaction time in methanol was determined according to the results measured at $515 \mathrm{~nm}$ by spectrophotometer (Varian Cary 50 Bio, UV / VIS Spectrophotometer). This method is based on the scavenging of DPPH radicals by antioxidants due to a redox reaction. ${ }^{1}$

\section{5. 3. Determination of Total Phenolic Content (TPC)}

The total phenolic content of the fucoxanthin extracts was defined spectrophotometrically using the Folin-Ciocalteu method according to. ${ }^{22}$

\section{Results and Discussion}

In this study, three different extraction methods, namely ultrasound (UE) and microwave (ME) and ho- 


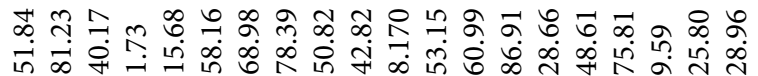

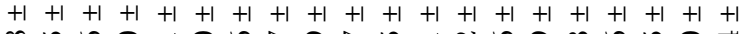
$\infty$ 냥 \&

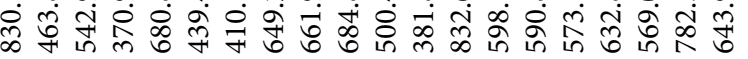

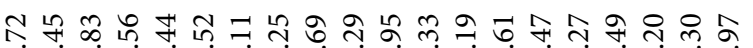
+ लं० $+1+1+1+1+1+1+1+1+1+1+1+1+1+1+1+1+1+1+1+1$

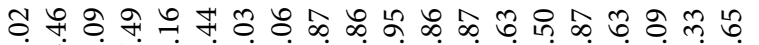
बें तें

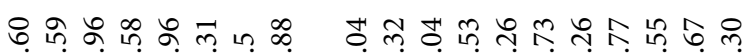
- jo. $+1+1+1+1+1+1+1+1+1+1+1+1+1+1+1+1+1+1+1$

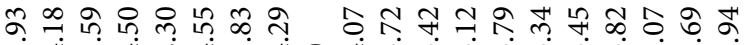

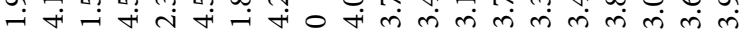

तิ 的 ஸ่ $+1+1+1+1+1+1+1+1+1+1+1+1+1+1+1+1+1+1+1+1$

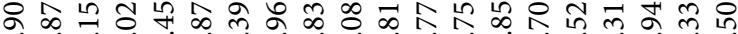

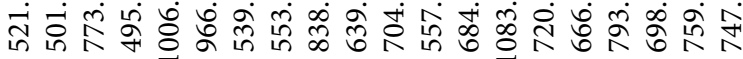

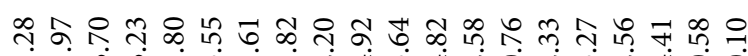
$+1+1+1+1+1+1+1+1+1+1+1+1+1+1+1+1+1+1+1+1$

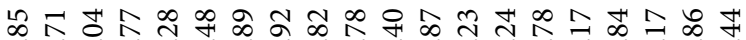

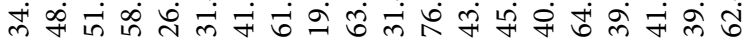

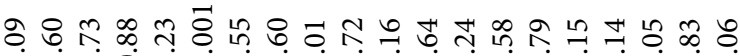

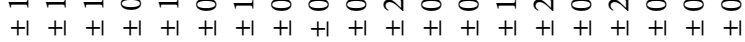
क $\infty$ 그 i

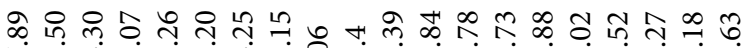

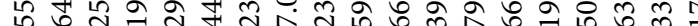

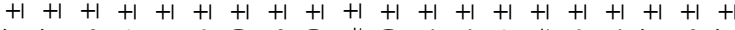

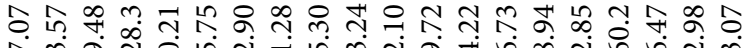
तิ

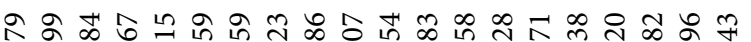
i。 $+1+1+1+1+1+1+1+1+1+1+1+1+1+1+1+1+1+1+1+1$ กิ่

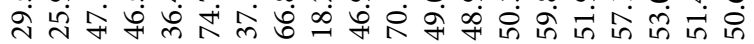

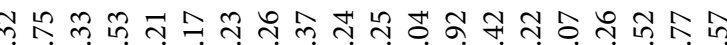

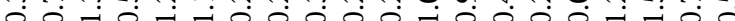
$+1+1+1+1+1+1+1+1+1+1+1+1+1+1+1+1+1+1+1+1$ సెल

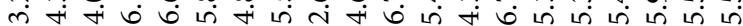

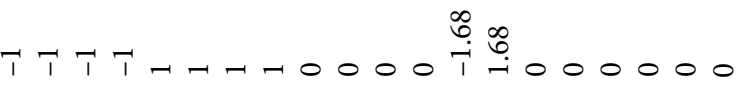

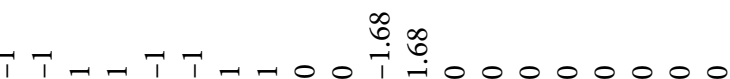

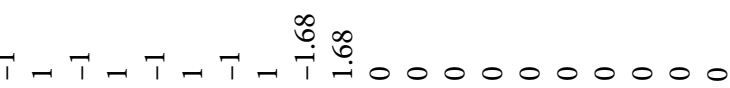




\section{章}

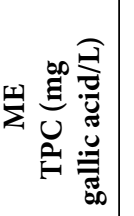

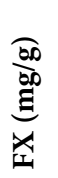

$=$

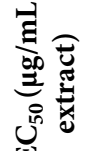
(1)

兰

st

됙 量哥

苨

2

कo

莺

压

总

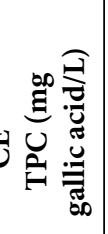

की

$\stackrel{\frac{30}{300}}{3}$

齐

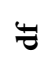

岇

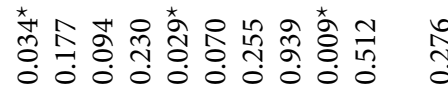

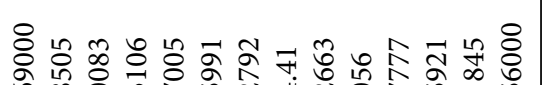

นึิ

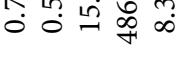

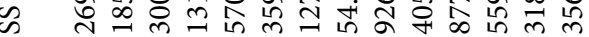

ई

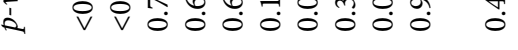

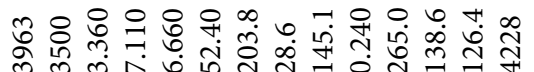

ڤิ

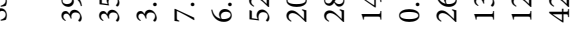

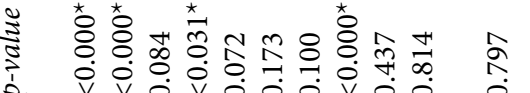

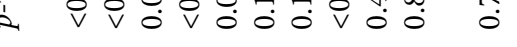

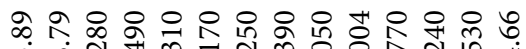

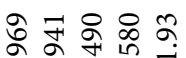

$\approx$ तुं

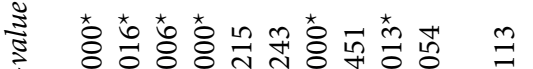

a.

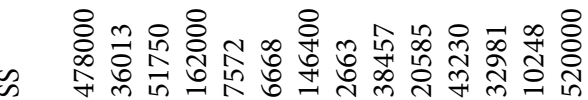

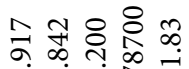

ò

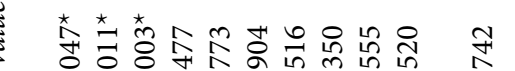

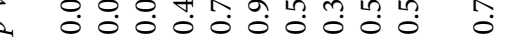

응 $\hat{n}$ 증

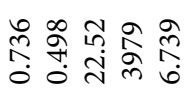

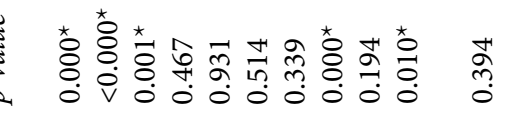

৩

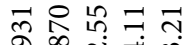

0

$\sum$

宽

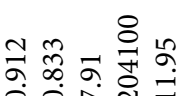

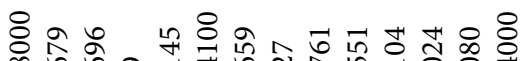

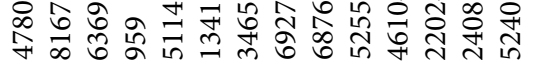

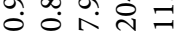

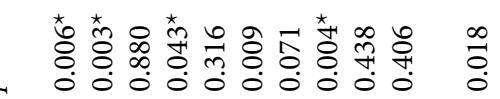

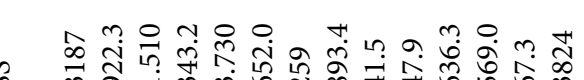

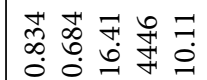

ma m

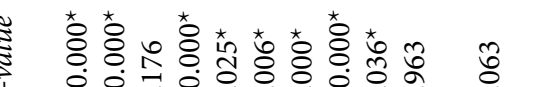

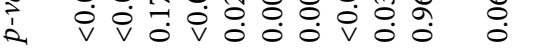

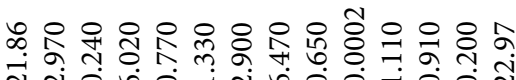

क ते तิ

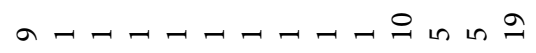

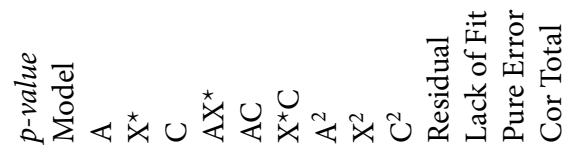

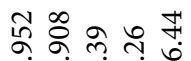

कें कुष त्र

(a)

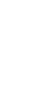


mogenization extraction (CE) were used to determine the effect of process conditions on fucoxanthin content (FX), total phenolic content (TPC) and DPPH antioxidant activity. The extraction process conditions arranged to CCRD (Table 2) were evaluated for responses; FX, TPC and DPPH antioxidant activity of the extracts. The experimental data are described to be compatible with the quadratic models (Eqs. 1, 2 and 3) $(p<0.05)$. The significance level of the effect of model terms on the responses and the suitability of the obtained models are given in Table 3 . In addition, the effects of the three extraction methods process conditions on the responses were explained in detail.

\section{1. Fucoxanthin Content (FX)}

The extraction method and conditions were found to be significant for the effective extraction of fucoxanthin. As given in Table 3, the extraction process conditions were the important factors for the extraction of fucoxanthin. Increasing the ratio of biomass/solvent increases dissolution of the solvent into cells and provides more extracts. Xu et al. ${ }^{25}$ explained that the excess solvent absorbed the cavitation energy in the extraction system and resulted in a lower extraction efficiency. The amount of fucoxanthin increased with increasing amount of biomass in all extraction methods (Fig. 1-3). Although the amount of fucoxanthin increased with the increase of biomass/solvent ratio in the homogenization extraction method (Fig. 1), the homogenization rate did not significantly affect the amount of fucoxanthin (Table 3). However, when the biomass/solvent ratio was maximum, the amount of fucoxanthin increased with the increase in the rate of homogenization in the short extraction process times. P. tricornutum, which has a silica structure needs to mechanical spalling. During CE period, this process breaks the outer silicon wall and accelerates the solvent uptake. That's why, the higher solvent uptake brought about the higher diffusivity through the cell walls. The high extraction efficiencies obtained by the CE method can be attributed to the fact that by breaking down the cell walls as a result of mechanical destroying, it can facilitate the washing of the cell contents. ${ }^{26}$ In the case of prolongation of the extraction time, the increase in homogenization rate showed a negative effect on the amount of fucoxanthin. The fucoxanthin appeared to degrade gradually during the long extraction period. ${ }^{11}$ This circumstance was also approved by the ANOVA results (Table 3). While the effect of homogenization rate on linear dimension was insignificant, the effect of homogenization rate and time interaction on fucoxanthin amount was statistically significant.

In the ultrasonic assisted extraction (UE) process, the amount of fucoxanthin increased with the increase of the biomass solvent ratio. Although the effect of the homogenization rate on the amount of fucoxanthin in the homogenization extraction process remained limited, the increase in the amplitude clearly resulted in an increase in the amount of fucoxanthin as seen in Fig. 2. The increase of amplitude increased the amount of fucoxanthin because the biomass and the solvent had a larger surface area in the UE due to effective cavitation and/or solvent penetration into the cell. The higher contact surface area between the solvent and the biomass also favored the extraction of phycocyanin..$^{24}$ The effect of extraction time in ultrasonic assisted extraction was not statistically found significant on fucoxanthin amount $(\mathrm{p}>0.05)$ (Table 3). However, Fig. 2 showed that short and long ultrasound application decreased the amount of fucoxanthin. Kim et al. ${ }^{11}$ reported that ethanol allowed to extract the highest fucoxanthin in the ultrasonic extraction process.

As in the other two extraction methods, the most effective independent variable on the amount of fucoxanthin in the microwave extraction method was the biomass solvent ratio. With the increase in the biomass solvent ratio, the amount of fucoxanthin obtained from P. tricornutum was increased by microwave extraction method. The effect of the extraction time and the microwave power on fucoxanthin extraction remained very limited in addition to the biomass/ solvent ratio. This was also confirmed by the change of fucoxanthin in Fig. 3 with respect to independent variables. However, the effect of the extraction time and microwave power on fucoxanthin should not be completely ignored. The shortening of the extraction time and the increase of microwave power resulted in an increase in the amount of fucoxanthin. Zhang et al. ${ }^{14}$ reported that the longer extraction time in microwave extraction method resulted in the lower yield of fucoxanthin. They explained this reduction as follows; the constant high temperature caused fucoxanthin deterioration.

The maximum fucoxanthin $(5.99 \pm 2.79 \mathrm{mg} / \mathrm{g})$ was extracted with UE method at $45 \%$ of amplitude for 17.5 min extraction time when the biomass/solvent ratio was $2 \%$. However, the maximum fucoxanthin $(4.55 \pm 0.31$ $\mathrm{mg} / \mathrm{g}$ ) was obtained when $3 \%$ biomass/solvent ratio, 100 $\mathrm{W}$ microwave power and $180 \mathrm{~s}$ of extraction time conditions were used in ME method (Table 2). Gilbert-Lopez et al. ${ }^{17}$ carried out fucoxanthin extraction $(4.59 \mathrm{mg} / \mathrm{g})$ from $P$. tricornutum by microwave assisted extraction in ethanol at $30^{\circ} \mathrm{C}$ for $2 \mathrm{~min}$. The $\mathrm{CE}$ method was more suitable for the extraction of fucoxanthin at maximum concentration $(6.78 \pm 0.25 \mathrm{mg} / \mathrm{g})$ (Exp. No: 11) for the biomass/solvent ratio of $2 \%$, homogenization rate of 3636 $\mathrm{rpm}$ and extraction time of $17.5 \mathrm{~min}$ as compared to the other methods. Although UE and ME increased extraction yields in many marine materials, the maximum fucoxanthin extraction was achieved in CE method. Kawee et al. ${ }^{27}$ explained the lower yield of fucoxanthin extraction by ultrasonic extraction by the rigid cell wall of $P$. tricornutum. Besides, Kim et al. ${ }^{11}$ also reported that ultrasonic assisted extraction method does not change the fucoxantin yield when compared with other extraction methods. Compared to the other two extraction methods, the lower amount of fucoxanthin was reached in the microwave extraction. However, the microwave ex- 
traction was superior to the other two methods in terms of extraction times. Pasquet et al. ${ }^{26}$ tried to extract fucoxanthin from Cylindrotheca closterium compared different extraction methods. Microwave extraction of C. closterium allowed total extraction of fucoxanthin in 3-5 min that equivalent to the yield obtained after $60 \mathrm{~min}$ soaking at $20^{\circ} \mathrm{C}$ or $56^{\circ} \mathrm{C}$.

\section{2. Total Phenolic Content (TPC)}

Phenolic compounds act as important antioxidants due to their skill to give a hydrogen atom or an electron to form stable radical intermediates. Extraction of $P$. tricornutum has significant pharmaceutical activities. Moreover, it uses as a safe food and sustainable feed source used in aquaculture. ${ }^{28}$ The total phenolic contents of extracts obtained with different extraction methods and conditions were determined and stated as gallic acid equivalent. The 3-D response surface graphs for TPC are shown in Fig. $1-3$. TPC was considerably affected from the biomass/solvent ratio for all extraction methods. For each extraction procedure, TPC content increased as the biomass/solvent ratio increased.

As expected, the excessive amount of biomass resulted in higher TPC content in the extraction medium due to diffusion of phenolic compounds through the extraction medium. The results showed that the biomass/solvent ratio caused significant differences in TPC in all extraction methods. (Table 3). Furthermore, UE method provided higher TPC content $(76.87 \pm 4.82 \mathrm{mg}$ gallic acid /L) (Table 2 ), due to tissue destruction as a function of time and intensity of ultrasound waves. Both et al. ${ }^{29}$ and Deng et al. ${ }^{30}$ explained the higher phenolic compounds releasing to extraction medium with the working principals of ultrasound extraction which caused acoustic cavitation, increasing temperature of extraction medium, lowering the particle size of biomass, cell wall fragmentation, rising the degree of solvent penetration into the cells. Several studies have reported that the TPC increased quickly with the increase of biomass ratio at room temperature, as well as by use of high temperature or in the existence of ultrasound. ${ }^{24}$ According to Pearson correlation test, fucoxanthin content was highly correlated with TPC and correlation coefficients ( $r$ ) were $0.645,0.707$ and 0.733 for CE, UE and ME, respectively. Foo et al. ${ }^{31}$ also observed a stronger correlation between major component of carotenoid (fucoxanthin) and phenolics (gallic acids). The maximum TPC (76.87 $\pm 4.82 \mathrm{mg}$ gallic acid/L) was found for the biomass/ solvent ratio of $2 \%$, amplitude of $70.22 \%$ and extraction time of 17.5 min with UE method whereas the minimum TPC ( $8.87 \pm 1.69 \mathrm{mg}$ gallic acid/L) was for biomass/solvent ratio of $0.32 \%$, microwave power of $150 \mathrm{~W}$ and extraction time of $120 \mathrm{~s}$ with ME method. In addition, CE method gave the maximum TPC $(74.77 \pm 0.59 \mathrm{mg}$ gallic acid/L) for biomass/solvent ratio of $3 \%$, homogenization rate of 5000 rpm and extraction time of $25 \mathrm{~min}$.

\section{3 DPPH Antioxidant Activity}

The DPPH (2,2-diphenyl-1-picrylhydrazyl or 1,1-diphenyl-2-picrylhydrazyl) scavenging test utilizes a stable nitrogen centered free radical. DPPH are effectively scavenged by antioxidants through the donation of hydrogen to form the reduced DPPH-H. ${ }^{32}$ This method has been commonly used to determine the antioxidant activity of brown seaweeds. Airanthi et al. ${ }^{33}$ reported that the antioxidant effect of seaweed was mainly due to the antioxidant activity of phenolic compounds. Holdt et al. ${ }^{34}$ also stated that many compounds possessing antioxidant activity that were isolated from brown algae were phenolic antioxidants. Moreover, brown algae have higher antioxidant activity than red or green algae. ${ }^{35}$ Fucoxanthin, the most abundant marine-based carotenoid, has been considered as a potential antioxidant activity, in terms of its free scavenging activity. ${ }^{36}$

The 3-D response surface graph of the predicted model for DPPH is shown in Fig. 1-3. The effect of biomass/solvent ratio and extraction time was statistically found significant on antioxidant activity of extracts (Table 3). The maximum DPPH antioxidant activity (1228.3 $\pm 25.07 \mathrm{EC}_{50} \mu \mathrm{g} / \mathrm{mL}$ extract) (Exp. No: 4) was for biomass/solvent ratio of $3 \%$, homogenization rate of 9000 rpm and extraction time of $10 \mathrm{~min}$ with CE method (Table 2). Whereas the minimum DPPH antioxidant activity $(370.9 \pm 1.73 \mu \mathrm{g} / \mathrm{mL}$ extract) (Exp. No: 4) was obtained for the biomass/solvent ratio of $3 \%$, microwave power of 200W and extraction time of $60 \mathrm{~s}$ with ME method (Table 2). ME method was not successful to extract fucoxanthin from biomass $P$. tricornutum with high antioxidant capacity. There are several studies about the investigation of antioxidant activity of fucoxanthin from different types of microalgae and macroalgae. ${ }^{19,27,33,35,37}$ Airanthi et al. ${ }^{33}$ have been reported to have observed the highest DPPH radical scavenging activity in methanol extract with 58.63 $\pm 5.24 \mu \mathrm{g}$ a-tocopherol equivalent per milligram and $33.46 \pm 4.69 \mu \mathrm{g} \alpha$-tocopherol equivalent per milligram for Eisenia bicyclis (Arame) and Kjellmaniella crassifolia (Gagome) macroalgae respectively. Foo et al. ${ }^{19}$ observed that Chaetoceros calcitrans extract with ethanol by homogenization extraction method (9500 rpm for $15 \mathrm{~min}$ ) exhibited the DPPH scavenging activity of $0.844 \mathrm{mg} / \mathrm{g}$ (dried weight).

\section{4. Optimization}

The process conditions of homogenization (CE), ultrasonic (UE) and microwave (ME) extraction methods in terms of ultrasound (amplitude) (\%), microwave power (W), homogenization rate $(\mathrm{rpm})$ biomass/solvent ratio (\%) and extraction time were optimized targeting maximum fucoxanthin content and acceptable amounts of total phenolic content and DPPH antioxidant activity. Graphical illustrations of the optimization were seen in Figure $1-3$. 

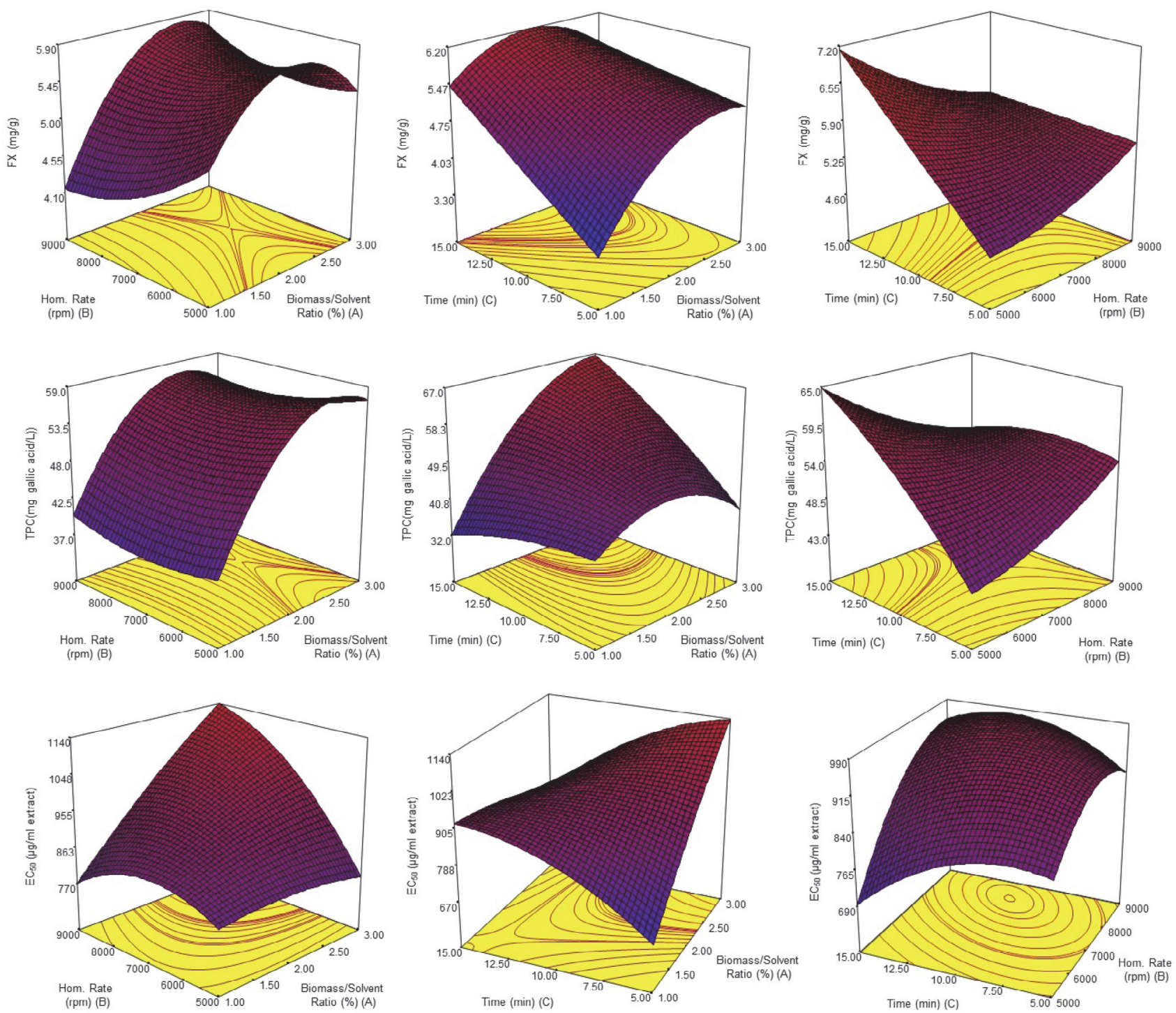

Figure 1. Calculated effects of homogenization extraction process variables on fucoxanthin content $(\mathrm{mg} / \mathrm{g})$, total phenolic content (mg gallic acid $/ \mathrm{L})$ and antioxidant activity $\left(\mathrm{EC}_{50} \mu \mathrm{g} / \mathrm{mL}\right.$ extract $)$.

The experimental data were well fitted to the second order polynomial models, as given in Table 3. The models of fucoxanthin content, TPC and DPPH antioxidant activity of extracts obtained from different extraction methods were statistically significant at level $p<0.05$. In order to define optimum extraction process conditions, desirability function approach was applied. The desirability function approach is commonly used to optimize multiple response processes.

When the desirability function approach was used, the optimum CE process conditions were $1.93 \%$ for the biomass/solvent ratio, $5203.25 \mathrm{rpm}$ for the homogenization rate and $14.20 \mathrm{~min}$ for the extraction time. The optimum process conditions for the extraction process carried out by the UE method were $2.72 \%$ for the biomass/solvent ratio, 55.72\% for the amplitude, and $17.37 \mathrm{~min}$ for the extraction time. ME method for fucoxanthin extraction gave the optimum process conditions as follows: $3.0 \%$ biomass/ solvent ratio, $100 \mathrm{~W}$ and $179.97 \mathrm{~s}$ extraction time. In order to validate these extraction conditions, five validation experiments were performed at these optimum extraction process conditions. The average value of FX was found to be significantly $(p<0.05)$ different from the predicted values, while TPC and DPPH antioxidant activity were not significantly $(p>0.05)$ different from the predicted values determined by Design Expert-version 7.0 software as given in Table 4.

A comparison was made to evaluate the results of each extraction method, given that the equipment and methods had their own characteristics and the experiments could not be performed under the same conditions. As given in Table 2, the highest amount of FX was obtained using homogenization and ultrasound extraction methods, while TPC was higher in homogenization method 

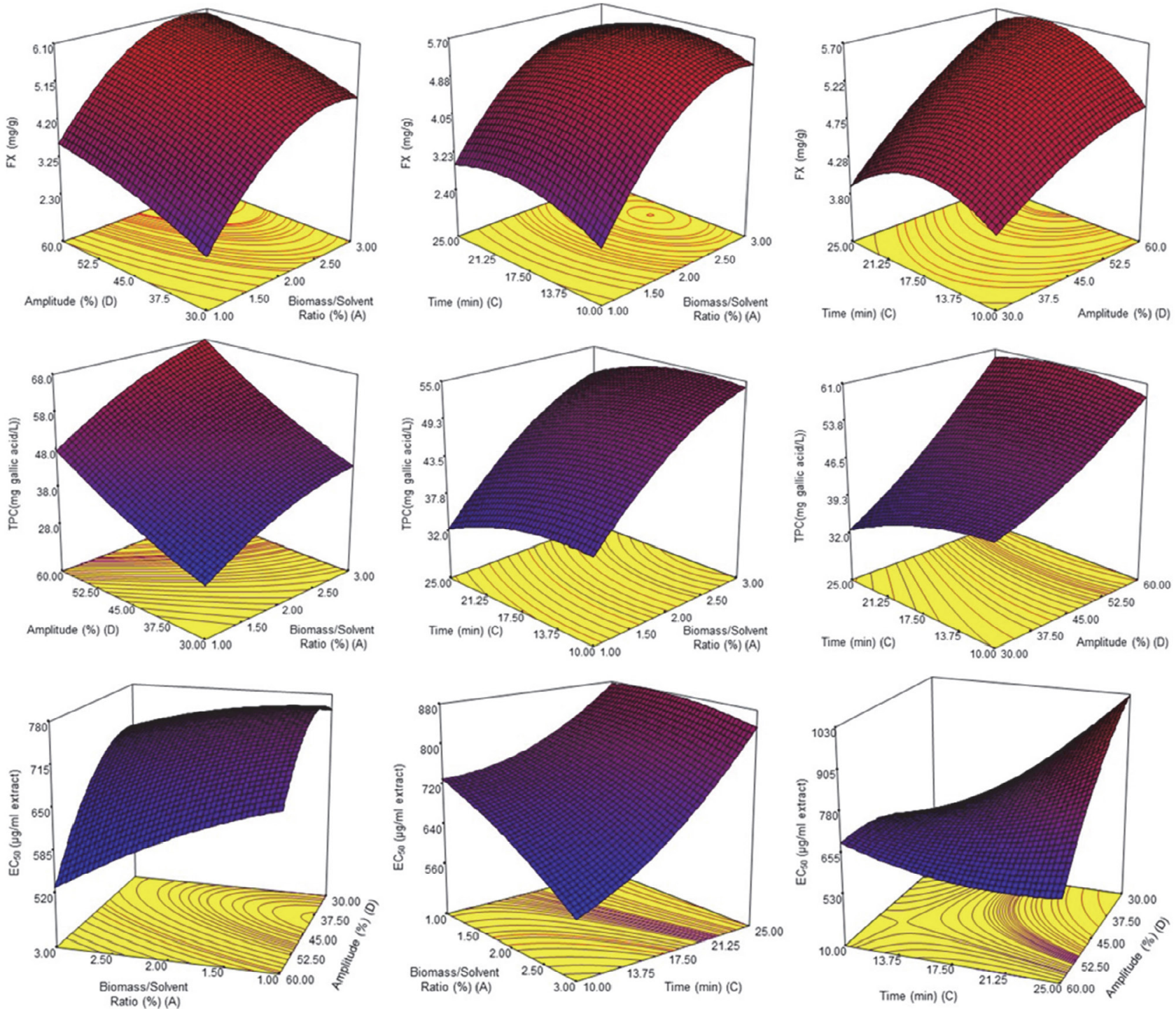

Figure 2. Calculated effects of ultrasound extraction process variables on fucoxanthin content $(\mathrm{mg} / \mathrm{g})$, total phenolic content ( $\mathrm{mg}$ gallic acid $/ \mathrm{L})$ and antioxidant activity $\left(\mathrm{EC}_{50} \mu \mathrm{g} / \mathrm{mL}\right.$ extract).

Table 4. Results of statistical analysis for verification of optimization

\begin{tabular}{|c|c|c|c|c|c|c|c|}
\hline $\begin{array}{l}\text { Extraction } \\
\text { method }\end{array}$ & Responses & $\begin{array}{l}\text { Predicted } \\
\text { Value }\end{array}$ & $\begin{array}{l}\text { Experimental } \\
\text { Value }^{\mathrm{x}}\end{array}$ & $\mathrm{SE}^{\mathrm{y}}$ & Difference & $\begin{array}{c}\% \\
\text { Error }^{\mathrm{z}}\end{array}$ & $\begin{array}{c}p- \\
\text { Value }\end{array}$ \\
\hline \multirow{3}{*}{$\mathrm{CE}$} & $\mathrm{FX}(\mathrm{mg} / \mathrm{g})$ & 6.83 & $5.60 \pm 0.06$ & 0.0299 & 1.237 & 22.05 & 0.000 \\
\hline & TPC (mg gallic acid /L) & 61.84 & $63.66 \pm 1.34$ & 0.669 & 1.824 & 2.86 & 0.053 \\
\hline & $\mathrm{DPPH}\left(\mathrm{EC}_{50} \mu \mathrm{g} / \mathrm{mL}\right.$ extract $)$ & 767.91 & $763.00 \pm 15.88$ & 7.939 & 4.91 & 0.64 & 0.570 \\
\hline \multirow{3}{*}{ UE } & $\mathrm{FX}(\mathrm{mg} / \mathrm{g})$ & 6.03 & $5.24 \pm 0.07$ & 0.035 & 0.79 & 15.07 & 0.000 \\
\hline & TPC (mg gallic acid /L) & 62.27 & $67.68 \pm 1.58$ & 0.787 & 5.413 & 7.997 & 0.002 \\
\hline & DPPH $\left(E_{50} \mu \mathrm{g} / \mathrm{mL}\right.$ extract $)$ & 615.82 & $619.90 \pm 17.16$ & 8.578 & 4.08 & 0.658 & 0.659 \\
\hline \multirow{3}{*}{$\mathrm{ME}$} & $\mathrm{FX}(\mathrm{mg} / \mathrm{g})$ & 4.49 & $4.11 \pm 0.04$ & 0.019 & 0.38 & 9.24 & 0.000 \\
\hline & TPC (mg gallic acid /L) & 40.68 & $40.87 \pm 2.69$ & 1.342 & 0.193 & 0.473 & 0.892 \\
\hline & DPPH $\left(\mathrm{EC}_{50} \mu \mathrm{g} / \mathrm{mL}\right.$ extract $)$ & 497.44 & $484.53 \pm 9.98$ & 4.992 & 12.91 & 2.66 & 0.061 \\
\hline
\end{tabular}

$\mathrm{x}$ Experimental values were expressed as mean \pm standard deviation

y Mean standard error

$z$ The $\%$ error=(|yexp-ypre $/$ yexp $) \times 100$ 

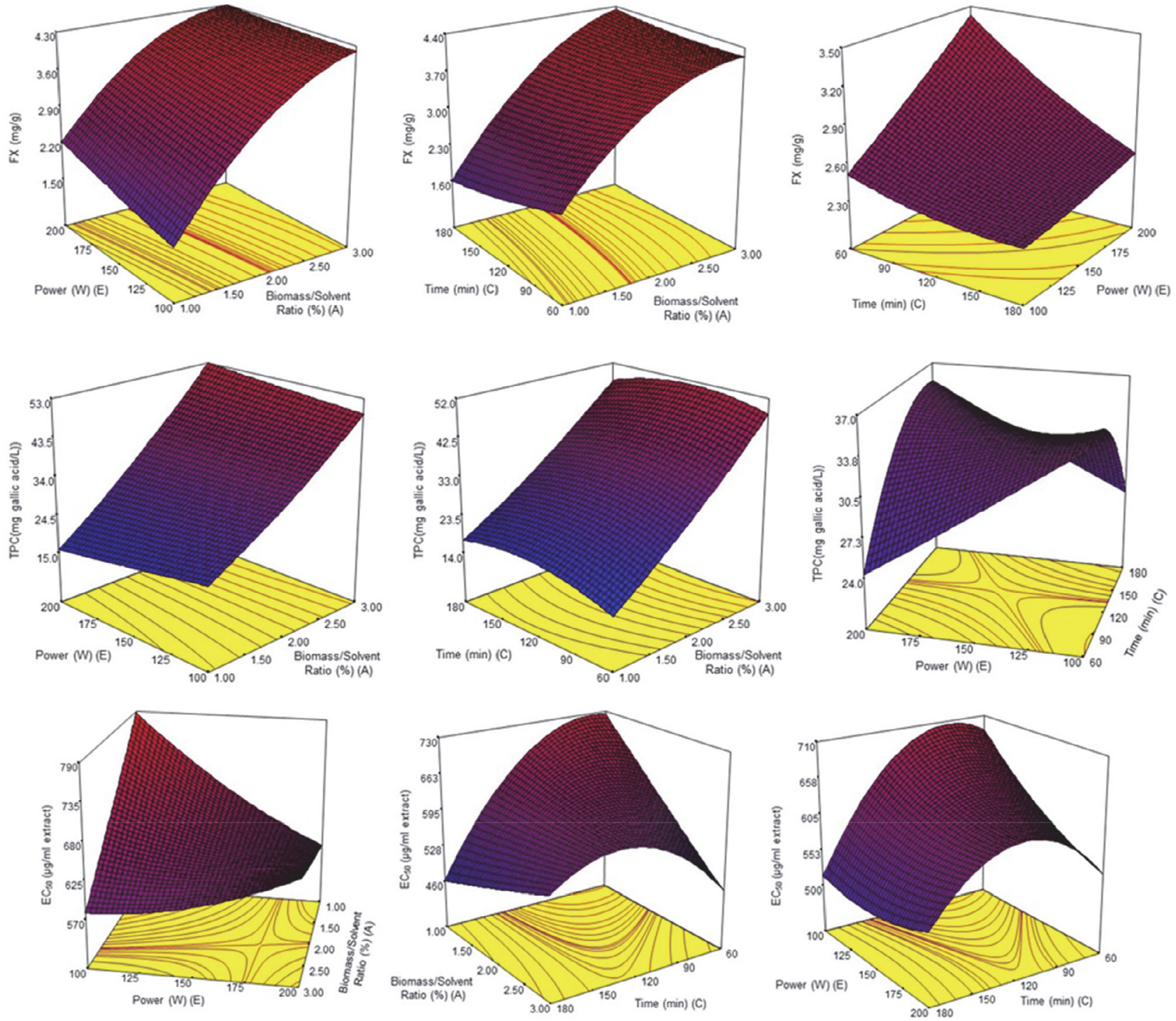

Figure 3. Calculated effects of microwave extraction process variables on fucoxanthin content (mg/g), total phenolic content (mg gallic acid /L) and antioxidant activity $\left(\mathrm{EC}_{50} \mu \mathrm{g} / \mathrm{mL}\right.$ extract).

than those obtained from other methods. The amounts of FX obtained by homogenization $(5.60 \pm 0.06 \mathrm{mg} / \mathrm{g})$ and ultrasound $(5.24 \pm 0.07 \mathrm{mg} / \mathrm{g})$ extraction methods were close to each other. However, when the biomass/solvent ratio (homogenization extraction: $1.93 \%$, ultrasonic extraction: $2.72 \%$ ) was compared, homogenization extraction method was found to be more effective than ultrasonic extraction method considering using less biomass.

\section{Conclusion}

In this study, the effects of extraction method and conditions on fucoxanthin and total phenolic compounds extracted from Phaeodactylum tricornutum were evaluated. The optimum points to provide the maximum FX and the acceptable TPC and DPPH antioxidant activity for the process conditions (biomass/solvent ratio, extraction time, amplitude specific to ultrasonic extraction, microwave power specific to microwave extraction and homogenization rate specific to homogenization extraction) of the extraction methods were determined for ultrasonic, microwave and homogenization extraction methods. It was found that the most effective independent variable in obtaining fucoxanthin from P. tricornutum was the biomass/ solvent ratio for three different extraction methods and the FX, TPC and DPPH antioxidant activity of the extracts increased with the increase in biomass ratio. However, the effect of the extraction time and the process parameters specific to the extraction method should not be ignored. The optimum conditions for all three extraction methods showed that the maximum fucoxanthin of the extracts was 
obtained with homogenization and ultrasound extraction methods. However, when the biomass/solvent ratio was compared, homogenization extraction method was found to be more effective than ultrasonic extraction due to using less biomass. This study showed that the extraction process parameters should be evaluated as a whole. In choosing the appropriate extraction method, extraction costs, applicability and sustainability concepts should be considered.

\section{Acknowledgments}

This study was a part of Cost Action ES1408 and the authors would like to thank The Scientific and Technological Research Council of Turkey (TUBITAK-115O578) for financial support.

\section{References}

1. S. Xia, K. Wang, L. Wan, A. Li, Q. Hu, C. Zhang, Mar. Drugs 2013, 11, 2667-2681. DOI:10.3390/md11072667

2. J. Peng, J. P. Yuan, C. F. Wu, J. H. Wang, Mar. Drugs 2011, 9, 1806-1828. DOI:10.3390/md9101806

3. E. Kotake-Nara, A. Nagao, Mar. Drugs 2011, 9, 1024-1037. DOI: $10.3390 / \mathrm{md} 9061024$

4. R. K. Sangeetha, N. Bhaskar, S. Divakar, V. Baskaran, Mol. Cell. Biochem. 2010, 333, 299-310.

DOI:10.1007/s11010-009-0231-1

5. P. Sun, C. C. Wong, Y. Li, Y. He, X. Mao, T. Wu, Y. Ren, F. Chen, Food Chem. 2019, 277, 566-572.

DOI:10.1016/j.foodchem.2018.10.133

6. M. Petrushkina, E. Gusev, B. Sorokin, N. Zotko, A. Mamaeva, A. Filimonova, M. Kulikovskiy, Y. Maltsev, I. Yampolsky, E. Guglya, V. Vinokurov, Z. Namsaraev, D. Kuzmin, Algal Res. 2017, 24, 387-393. DOI:10.1016/j.algal.2017.03.016

7. J. C. Kim, Sep. Sci. Technol. 2014, 49, 410-415. DOI:10.1080/01496395.2013.839703

8. A. Piovan, R. Seraglia, B. Bresin, R. Caniato, R. Filippini, Molecules 2013, 18, 6298-6310.

DOI:10.3390/molecules 18066298

9. A. Fung, N. Hamid, J. Lu, Food Chem. 2013, 136, 1055-1062. DOI:10.1016/j.foodchem.2012.09.024

10. H. Maeda, M. Hosokawa, T. Sashima, K. Funayama, K. Miyashita, Biochem. Biophys. Res. Commun. 2005, 332, 392-397. DOI:10.1016/j.bbrc.2005.05.002

11. S. M. Kim, Y. J. Jung, O. N. Kwon, K. H. Cha, B. H. Um, D. Chung, C. H. Pan, Appl. Biochem. Biotechnol. 2012, 166, 1843-1855. DOI:10.1007/s12010-012-9602-2

12. L. J. Wang, Y. Fan, R. Parsons, G. R. Hu, P. Y. Zhang, F. L. Li, Mar. Drugs 2018, 16,33. DOI:10.3390/md16010033

13. A. Gómez-Loredo, J. González-Valdez, M. GonzálezGonzález, J. Benavides, M. Rito-Palomares, J. Chem. Technol. Biotechnol. 2018, 93, 2033-2039. DOI:10.1002/jctb.5494

14. W. Zhang, F. Wang, B. Gao, L. Huang, C. Zhang, Algal Res. 2018, 32, 193-200. DOI:10.1016/j.algal.2018.04.002
15. H. Wu, T. Li, G. Wang, S. Dai, H. He, W. Xiang, Chinese J. Oceanol. Limnol. 2016, 34, 391-398.

DOI:10.1007/s00343-015-4325-1

16. A. R. Fajardo, L. E. Cerdán, A. R. Medina, F. G. A. Fernández, P. A. G. Moreno, E. M. Grima, Eur. J. Lipid Sci. Technol. 2007, 109, 120-126. DOI:10.1002/ejlt.200600216

17. B. Gilbert-López, A. Barranco, M. Herrero, A. Cifuentes, E. Ibáñez, Food Res. Int. 2017, 99, 1056-1065.

DOI:10.1016/j.foodres.2016.04.022

18. D. D. McClure, A. Luiz, B. Gerber, G. W. Barton, J. M. Kavanagh, Algal Res. 2018, 29, 41-48.

DOI:10.1016/j.algal.2017.11.015

19. S. C. Foo, F. M. Yusoff, M. Ismail, M. Basri, N. M. H. Khong, K. W. Chan, S. K. Yau, Asian Pac. J. Trop. Biomed. 2015, 5, 834-840. DOI:10.1016/j.apjtb.2015.06.003

20. R. R. L. Guillard, J. H. Ryther, Can. J. Microbiol. 1962, 8, 229 239. DOI:10.1139/m62-029

21. Z. Demirel, R. Tok, I. İlter, S. Akyll, A. Erdoğan, M. Koç, F. Kaymak-Ertekin, M. Conk-Dalay, Aquat. Res. 2018, 1, 52-64. DOI:10.3153/AR18008

22. I. İlter, S. Akyıl, Z. Demirel, M. Koç, M. Conk-Dalay, F. Kaymak-Ertekin, J. Food Compos. Anal. 2018, 70, 78-88.

DOI:10.1016/j.jfca.2018.04.007

23. A. Erdogan, Z. Demirel, M. Conk-Dalay, A. E. Eroglu, Turkish J. Fish. Aquat. Sci. 2016, 16, 491-498.

DOI:10.4194/1303-2712-v16_3_01

24. G. Oboh, LWT - Food Sci. Technol. 2005, 38, 513-517. DOI:10.1016/j.lwt.2004.07.007

25. Y. Xu, F. Cai, Z. Yu, L. Zhang, X. Li, Y. Yang, G. Liu, Food Chem. 2016, 194, 650-658.

DOI:10.1016/j.foodchem.2015.08.061

26. V. Pasquet, J. R. Chérouvrier, F. Farhat, V. Thiéry, J. M. Piot, J. B. Bérard, R. Kaas, B. Serive, T. Patrice, J. P. Cadoret, L. Picot, Process Biochem.2011, 46, 59-67.

DOI:10.1016/j.procbio.2010.07.009

27. A. Kawee-ai, A. Kuntiya, S. M. Kim, Nat. Prod. Commun. 2013, 8, 1381-6. DOI:10.1177/1934578X1300801010

28. H. Maeda, S. Fukuda, H. Izumi, N. Saga, Mar. Drugs 2018, 16, 255. DOI: $10.3390 / \mathrm{md} 16080255$

29. S. Both, F. Chemat, J. Strube, Ultrason. Sonochem. 2014, 21, 1030-1034. DOI:10.1016/j.ultsonch.2013.11.005

30. Y. Deng, Y. Zhao, O. Padilla-Zakour, G. Yang, Ind. Crops Prod. 2015, 74, 803-809. DOI:10.1016/j.indcrop.2015.06.014

31. S. C. Foo, F. M. Yusoff, M. Ismail, M. Basri, S. K. Yau, N. M. H. Khong, K. W. Chan, M. Ebrahimi, J. Biotechnol. 2017, 241, 175-183. DOI:10.1016/j.jbiotec.2016.11.026

32. W. Brand-Williams, M. E. Cuvelier, C. Berset, LWT - Food Sci. Technol. 1995, 28, 25-30. DOI:10.1016/S0023-6438(95)80008-5

33. M. K. W. A. Airanthi, M. Hosokawa, K. Miyashita, J. Food Sci. 2011, 76, 104-11. DOI:10.1111/j.1750-3841.2010.01915.x

34. S. L. Holdt, S. Kraan, J. Appl. Phycol. 2011, 23, 543-597. DOI:10.1007/s10811-010-9632-5

35. E. M. Balboa, E. Conde, A. Moure, E. Falqué, H. Domínguez, Food Chem. 2013, 138, 1764-1785.

DOI:10.1016/j.foodchem.2012.11.026 
36. N. M. Sachindra, E. Sato, H. Maeda, M. Hosokawa, Y. Niwano, M. Kohno, K. Miyashita, J. Agric. Food Chem. 2007, 55 , 8516-8522. DOI:10.1021/jf071848a
37. S. C. Foo, F. M. Yusoff, M. Ismail, M. Basri, S. K. Yau, N. M. H. Khong, K. W. Chan and M. Ebrahimi, J. Biotechnol, 2017, 241, 175-183. DOI:10.1111/j.1750-3841.2010.01915.x

\section{Povzetek}

Preučili smo vpliv ekstrakcije s homogenizacijo, ultrazvokom in mikrovalovi, ter pogoje ekstrakcije, na vsebnost fukoksantina in celotnih fenolov ter antioksidativno aktivnost ekstraktov pridobljenih iz Phaeodactylum tricornutum. Za vse troje se je kot najpomembnejši dejavnik izkazalo razmerje med količino topila in biomase. Najvišjo vsebnost fukoksantina $(5.60 \pm 0.06 \mathrm{mg} / \mathrm{g})$ in antioksidativne aktivnosti $(763.00 \pm 15.88 \mathrm{EC} 50 \mu \mathrm{g} / \mathrm{mL}$ ekstrakta) smo dosegli z ekstrakcijo s homogenizacijo pri razmerju biomasa/topilo $1.93 \%$, homogenizacijo pri $\sim 5200 \mathrm{rpm}$ in časom ekstrakcije $14.2 \mathrm{~min}$. Čeprav smo pri ekstrakciji z mikrovalovi dosegli približno enako stopnjo vsebnosti fukoksantina $(5.24 \pm 0.07 \mathrm{mg} / \mathrm{g})$, TPC $(67.68 \pm 1.58 \mathrm{mg}$ galne kisline/L) in antioksidativne aktivnosti $(619.90 \pm 17.16 \mathrm{EC} 50 \mu \mathrm{g} / \mathrm{mL}$ ekstrakta $)$ pri amplitudi $55.72 \%$, smo za to potrebovali višje razmerje biomasa/topilo (2.72 \%) in daljši čas ekstrakcije (17.37 min). Najnižja vsebnost fukoksantina in TPC ter antioksidativna aktivnost pa so bili določeni pri ekstrakciji z mikrovalovi.

Except when otherwise noted, articles in this journal are published under the terms and conditions of the Creative Commons Attribution 4.0 International License 